\title{
Reduction of Radiocesium Transfer to Animal Products Using Sustained Release Boli with Ammoniumiron(III)-Hexacyanoferrate(II)
}

\author{
By K. Hove and H. S. Hansen
}

Department of Animal Science, Agricultural University of Norway, Ås, Norway.

\begin{abstract}
Hove, K. and H. S. Hansen: Reduction of radiocesium transfer to animal products using sustained release boli with ammoniumiron (III) - hexacyanoferrate (II). Acta vet. scand. 1993, 34, 287-297. - A sustained release bolus with the cesium binder ammoniumiron(III) - hexacyanoferrate (AFCF) has been developed as a countermeasure for small ruminants grazing pastures contaminated by radiocesium $\left({ }^{134} \mathrm{Cs}+{ }^{137} \mathrm{Cs}\right)$. The boli (40-50 g) are produced by compression of a mixture of AFCF, barite and wax. The release of AFCF from boli labelled with 137Cs-iron-hexacyanoferrate complex was studied in laboratory sheep. The release rate followed first order kinetics during the $108 \mathrm{~d}$ of observation and decreased from 40 to 22,110 to 35 and 280 to $25 \mathrm{mg} \mathrm{d}^{-1}$ in sheep treated with 1,2 or 3 boli respectively. The efficiency of boli in reducing radiocesium transfer to meat and milk was tested in laboratory studies with goats fed ${ }^{134} \mathrm{Cs}$ tracer. Until $40 \mathrm{~d}$ after treatment the transfer of radiocesium to milk was reduced by $35 \%$, $60 \%$ and $85 \%$ in goats given 1,2 or 3 boli, respectively. The reduction in radiocaesium transfer persisted for $90 \mathrm{~d}$ but with a lower efficiency. A similar relationship was found between number of boli and the reduction in radiocesium transfer to meat with an observed maximal reduction of $60 \%$.
\end{abstract}

cesium binder, contamination; sheep; goat; milk; meat; release rates from bolus.

\begin{abstract}
Introduction
After the Chernobyl accident a large number of sheep, goats and reindeer had radiocesium activity concentrations greatly exceeding national intervention levels in several European countries (Hove \& Ekern 1988, Howard \& Beresford 1989, Jones et al. 1989, Pearce et al. 1989). Hexacyanoferrate compounds bind cesium strongly and will efficiently reduce radiocesium uptake in the gut (Nigrovic 1963). In the years after 1986 hexacyanoferrates have been approved for general use in Norway for reduction of radiocesium uptake in grazing ruminants (Hove et al. 1990). The ammonium salt (AFCF) appears to be the most commonly used iron-hexacyanoferrate compound. AFCF is highly specific to cesium ( $\mathrm{Wa}$ -
\end{abstract}

tari et al. 1968), non-toxic in farm animals ( $A r$ naud et al. 1988, Giese 1988, Pearce et al. 1989) and much more efficient as cesium binder than bentonite and other clay minerals (Giese 1989, Unsworth et al. 1989, Daburon et al. 1991). Recommended levels of AFCF to farm animals have been $6 \mathrm{mg} \mathrm{kg}^{-1}$ body weight to cows, and $20-40 \mathrm{mg} \mathrm{kg}^{-1}$ to small ruminants (Giese 1989). In a recent study (Hove et al. 1991) doses of only 1 and $3 \mathrm{mg} \mathrm{kg}^{-1}$ body weight reduced radiocesium transfer from feed to red blood cells in reindeer by $50 \%$ and $80 \%$ respectively. The high binding capacity of AFCF makes it well suited for use in controlling radiocesium accumulation in farm animals. Apart from the use as a feed supple- 


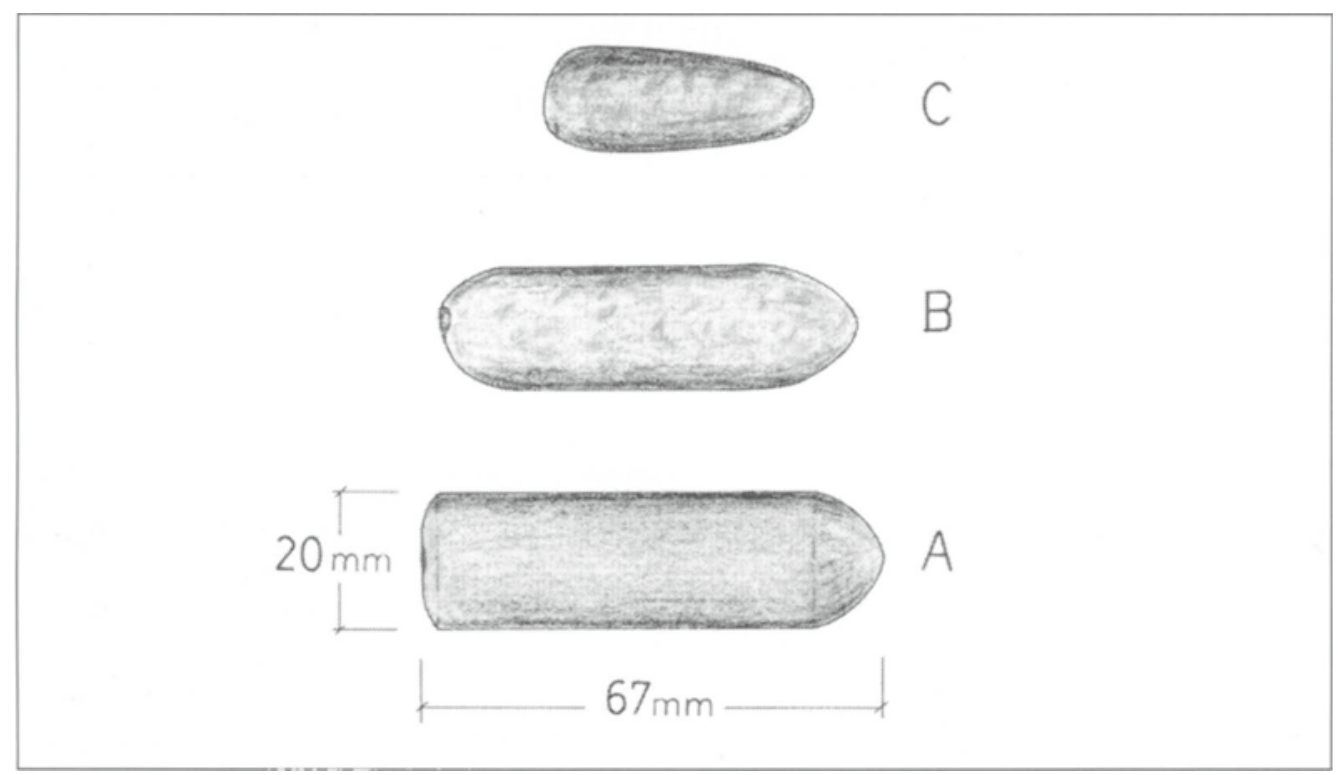

Figure 1. Relative size and shape of a sustained release bolus with AFCF before treatment (A), after 3 weeks (B) and after 2 months (C) in sheep given 2 boli.

ment included in rations of concentrates or complete diets, AFCF has also been given as a salt lick and a sustained release bolus (Pearce et al. 1989, Hove et al. 1990). The sustained release boli used in the experiment by Pearce et al. (1989) were produced in our laboratory with saturated fatty acid as the binding agent. Further development revealed that substitution of saturated fatty acids with waxes and use of mechanical compression during production of the boli increased their efficiency. The present study describes the de-

${ }^{1}$ Giesesalt with $65-70 \%$ ammoniumiron(III)-hexacyanoferrate(II) and 30-35\% $\mathrm{NH}_{4} \mathrm{Cl}$, Riedel-de Haën AG, D-3016 Seelze 1, Germany.

${ }^{2}$ Cera alba, Norsk Medisinaldepot, P.O.Box 100, Veitvet, N-0518 Oslo 5, Norway.

${ }^{3}$ API/OCMA quality, Anchor Drilling Fluids AS, Gl. Forusveien 43, N-4033 Stavanger, Norway. sign of such boli, the rate of release of AFCF and the efficiency of the boli in reducing radiocesium transfer to meat and milk in small ruminants maintained under laboratory conditions.

\section{Materials and methods}

\section{Sustained release boli}

The composition of the boli were (by weight) $15 \%$ ammoniumiron(III)-hexacyanoferrate $(\mathrm{AFCF})^{1}, 10 \%$ bees wax ${ }^{2}$ and $75 \%$ barite $^{3}$. The wax was melted at $80^{\circ} \mathrm{C}$ and $\mathrm{AFCF}$ and barite were added. The ingredients were mixed thoroughly under heating, until the temperature of the mixture was $80^{\circ} \mathrm{C}$. The mixture was then spread out in a thin layer for cooling. Boli were made by compression in a stainless steel mould using a pressure of 12.7$16 * 10^{6} \mathrm{~Pa}$. Boli for lambs were $18 \mathrm{~mm}$ in diameter, $67 \mathrm{~mm}$ long and weighed $40 \mathrm{~g}$ (39-41 g). 
Table 1. Summary of experimental conditions. Total number of animals, body weight, milk yield, use of tracer, weight of boli and duration of the different experiments.

\begin{tabular}{llcccccc}
\hline Experiment & Animals & No & $\begin{array}{c}\text { Body weight } \\
\mathrm{kg}\end{array}$ & $\begin{array}{c}\text { Yield } \\
\mathrm{ld}^{-1}\end{array}$ & Tracer & $\begin{array}{c}\text { Boli weight } \\
\mathrm{g}\end{array}$ & $\begin{array}{c}\text { Duration } \\
\text { days }\end{array}$ \\
\hline Experiment 1 & Rams & 12 & $80-95$ & - & ${ }^{137} \mathrm{Cs}$ & $39-41$ & 108 \\
Experiment 2 & Goats & 16 & $36-53$ & $0.5-1.7$ & ${ }^{134} \mathrm{Cs}$ & $39-41$ & 43 \\
Experiment 3 & Goats & 10 & $40-58$ & $1.6-3.2$ & ${ }^{134} \mathrm{Cs}$ & $35-39$ & 87 \\
Experiment 4 & Goats & 4 & $38-55$ & $1.7-4.4$ & ${ }^{134} \mathrm{Cs}$ & $35-38$ & 73 \\
\hline
\end{tabular}

$*^{*} \mathrm{~d}^{-1}$ : liter per day.

Boli for adult sheep and goats were $20 \mathrm{~mm}$ in diameter, $67 \mathrm{~mm}$ long and weighed $50 \mathrm{~g} \mathrm{(49-51}$ g). The density of the boli was $2.6 \mathrm{~kg} \mathrm{l}^{-1}$. The general shape and size of boli recovered in sheep slaughtered at different times after treatment in preliminary experiments are given in Fig. 1.

\section{Treatment of animals}

Boli should be lubricated with paraffin oil prior to administration. Sheep and goats will swallow the boli when placed on the posterior part of the tongue. In lambs up to 4 months of age boli can be given by a gloved hand. For larger animals boli must be placed at the back of the tongue by means of an applicator as for instance a short piece of rubber hose.

Experiment 1: Rate of release of $\mathrm{AFCF}$ from boli. Release rates of AFCF from boli were calculated from measurements of fecal excretion of ${ }^{137} \mathrm{Cs}$ traced iron-hexacyanoferrate incorporated in the boli. To prepare these boli, $10 \mathrm{~g}$ AFCF were suspended in $100 \mathrm{ml} \mathrm{H}_{2} \mathrm{O}$ and $4.5 \mathrm{MBq}^{137} \mathrm{CsCl}^{4}$ was added and the mixture stirred for $1 \mathrm{~h}$ at $20^{\circ} \mathrm{C}$. The suspension of ${ }^{137} \mathrm{Cs}$-iron-hexacyanoferrate complex was evaporated to dryness, and the

\footnotetext{
${ }^{4}$ Amersham International, Buckinghamshire, England HP7 9NA, United Kingdom.
}

residue ground in a mortar. This powder was mixed with $170 \mathrm{~g} \mathrm{AFCF}$ and used for bolus production as described above.

The 12 rams used in the experiment (Table 1) were divided in 3 groups and were given 1, 2 or 3 boli each. The animals were kept in metabolism cages and fed hay, grass silage, or roughage plus concentrate diets at maintenance level. All feeds had a negligible radiocesium content. Feces was collected every second day for $108 \mathrm{~d}$. Each collection was mixed and one half (200-450 g dry matter) was dried and ground to a particle size of $1 \mathrm{~mm}$. The ${ }^{137} \mathrm{Cs}$ content was measured on duplicate samples of 4-10 $\mathrm{g}$ feces. At the end of the experiment a urine sample was taken from each animal and a $20 \mathrm{ml}$ aliquot was measured for ${ }^{137} \mathrm{Cs}$ activity concentration.

Experiment 2, 3 and 4 were conducted to test the reduction of ${ }^{134} \mathrm{Cs}$ transfer to milk and meat of goats (Norwegian dairy goats) treated with AFCF boli (Table 1). The animals were individually fed dairy concentrate $(12 \%$ crude protein) proportionate to milk yield and hay or grass silage ad lib. An aqueous solution of 2 or $5 \mathrm{ml}$ containing ${ }^{134} \mathrm{CsCl}^{5}$ (specific activity 203-414 MBq mg-1 Cs) and $10 \mathrm{mmol} \mathrm{l}^{-1} \mathrm{HCl}$ was given on the concentrate in the morning and evening. The concentrate was consumed before roughage was fed. Milk samples were taken twice weekly and a $20 \mathrm{ml}$ aliquot was used to measure ${ }^{134} \mathrm{Cs}$ activity concentration. 


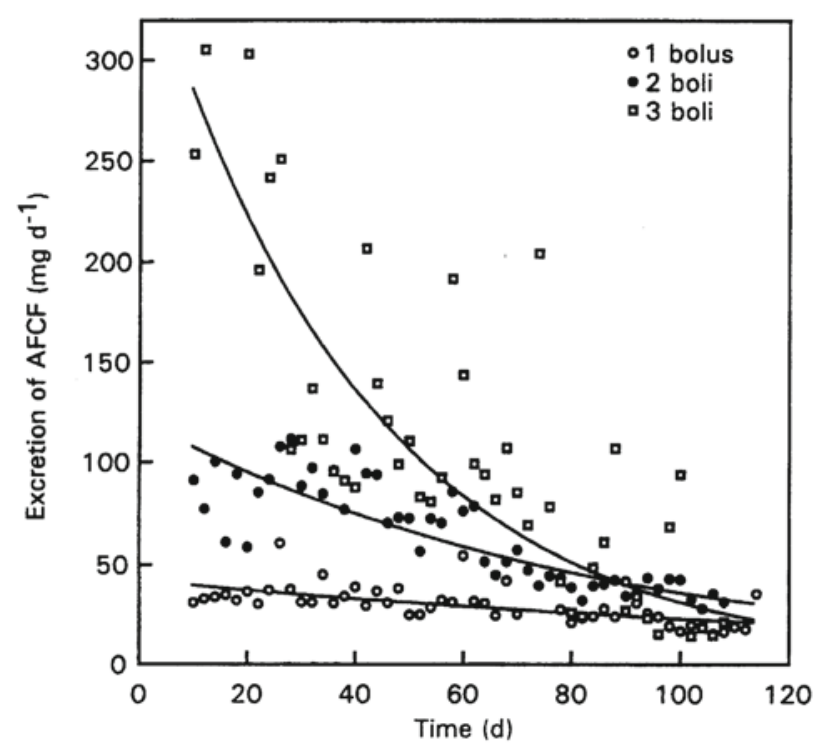

Figure 2. Mean daily fecal excretion of AFCF from rams treated with 1, 2 or 3 boli in experiment 1 . The graphs represent the best fit of a single exponential function to the observed data. (Means of 4 animals).

Experiment 2: Effect of different numbers of boli. Sixteen goats in the eighth and ninth month of lactation were divided into 4 groups of which each goat was treated with $0,1,2$ or 3 boli (Table 1). A solution of $1870 \mathrm{~Bq}{ }^{134} \mathrm{CsCl}$ was given daily for 43 d. Live monitoring was used at the end of the experiment to measure the $134 \mathrm{Cs}$ activity concentration in meat.

Experiment 3: Longterm efficiency of boli. Six goats were given 2 sustained release boli each at the start of the experiment and 4 goats were used as controls (Table 1). The experiment started 3 to 4 weeks after kidding. A solution of $2360 \mathrm{~Bq}{ }^{134} \mathrm{CsCl}$ was given daily. Milk ${ }^{134} \mathrm{Cs}$ activity concentrations were measured for 87 days.

Experiment 4: Efficiency of boli after storage. Boli from the same batch as in ex- periment 3 were used 1 year after production. Two goats were each treated with 2 boli stored at room temperature, and 2 other goats received boli stored at $4^{\circ} \mathrm{C}$ (Table 1). The experiment started 3 to 4 weeks after kidding. A solution of $2620 \mathrm{~Bq}{ }^{134} \mathrm{CsCl}$ was given for 73 days.

\section{Radiometry}

Measurements of ${ }^{134} \mathrm{Cs}$ and ${ }^{137} \mathrm{Cs}$ activity concentrations in milk, urine and feces were performed by gamma spectrometry using a $\mathrm{NaI}(\mathrm{Tl})$ scintillation detector ${ }^{5}$. The feces was counted for 2-12 min and milk and urine for $30 \mathrm{~min}$ to obtain standard deviations of less

\footnotetext{
${ }^{5}$ Packard Minaxi auto $\gamma 5000$ series, Packard Instrument Company, One State Street, Merinden, CT 06450, USA

${ }^{6}$ Canberra Series 10, Canberra Industries, Inc., One State Street, Merinden, CT 06450, USA.
} 


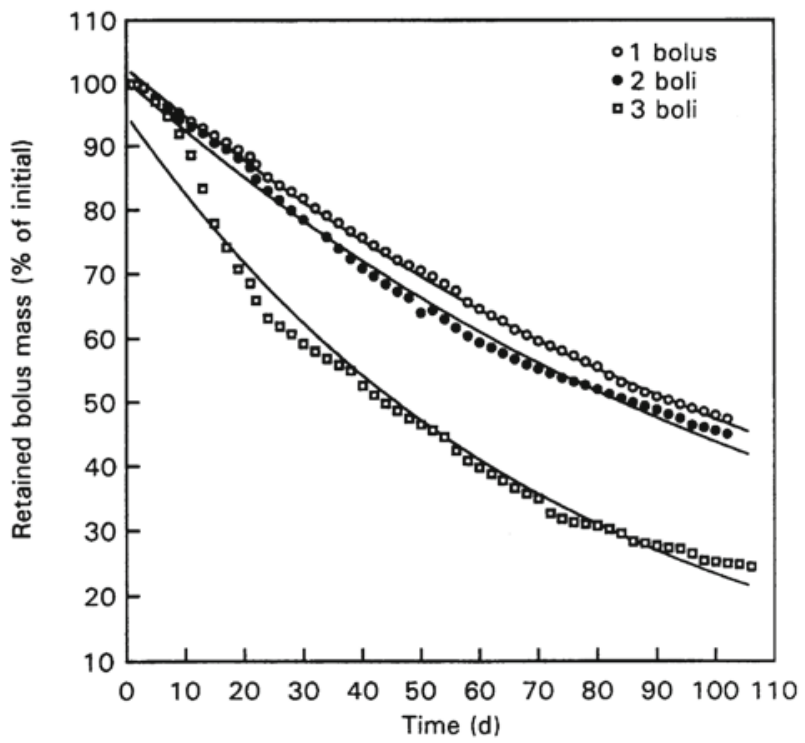

Figure 3. Mean relative retained bolus mass in rams treated with 1,2 or 3 boli in experiment 1 . The graphs represent the best fit of a single exponential function to the observed data. (Means of 4 animals).

than $3 \%$. Measurements were performed by the Isotope Laboratory at the Agricultural University. A portable counter ${ }^{6}$ with a $\mathrm{NaI}(\mathrm{Tl})$ scintillator $(7.5 \mathrm{~cm}$ diameter and height) was used for the live monitoring measurements. The measuring method was changed from that described by Strand \& Brynhildsen (1990) to placing the probe firmly against the thigh, measuring for $60 \mathrm{~s}$ and changing the efficiency factor accordingly.

\section{Calculations}

In experiment 1 the daily mean excreted amount of AFCF (Y) for the 4 animals in each group (Fig. 2) and the mean retained mass of the boli relative to the initial mass (Fig. 3) were fitted to single exponential functions

$$
\mathrm{Y}\left(\mathrm{mg} \mathrm{d}^{-1} \text { or } \%\right)=\mathrm{A}^{*} \mathrm{e}^{\left(-\mathrm{k}^{*} \mathrm{t}\right)}
$$

where $t$ was the time in days since treatment. When calculating the rate of AFCF excretion,
A was the excreted amount at day 0 and $\mathrm{k}$ the fractional rate constant for the release rate of AFCF. Observations from day 1-10 were excluded from the calculations to allow for the time required for $\mathrm{AFCF}$ in feces to reach a steady state concentration corresponding to the release rate from the boli in the rumen-reticulum. When calculating the relative retained boli mass, A was the relative initial mass and $\mathrm{k}$ the fractional rate constant for the daily excretion of boli mass. The fractional rate constants were compared using regression analysis (SAS Institute Inc. 1990).

Transfer coefficients of ${ }^{134} \mathrm{Cs}$ to milk $\left(\mathrm{F}_{\mathrm{m}}\right)$ and meat $\left(\mathrm{F}_{\mathrm{f}}\right)$ were calculated as outlined by Ward \& Johnson (1986). $\mathrm{F}_{\mathrm{m}}$ values were calculated for observations after the 10th day of administration. The $F_{\mathrm{f}}$ values in experiment 2 were calculated at day 43 of administration. $\mathrm{F}_{\mathrm{m}}$ and $F_{f}$ values were compared using one way analysis of variance (SAS Institute Inc. 1990). A p $<0.05$ was taken to be significant. 


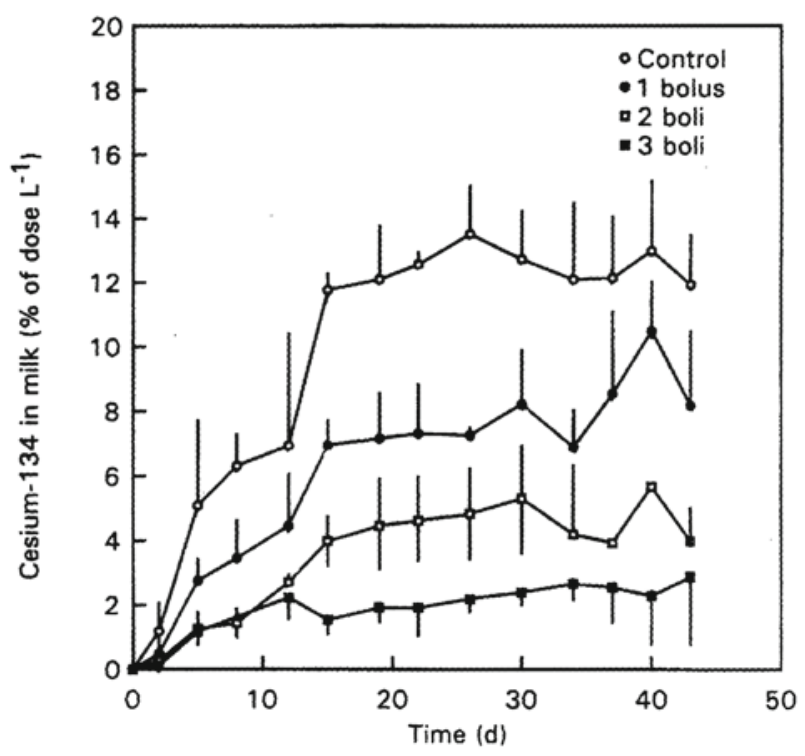

Figure 4. Fraction of the daily administered ${ }^{134} \mathrm{Cs}$ amount transferred to milk in control goats and goats treated with 1,2 or 3 boli in experiment 2 . A solution of $1870 \mathrm{~Bq}{ }^{134} \mathrm{Cs}$ was given daily for 43 days. (Mean and standard deviations for 4 goats).

\section{Results}

\section{Experiment 1}

Single exponential functions were used to fit the excretion of AFCF (Fig. 2) and the relative retention of bolus mass (Fig. 3) because simple linear regressions resulted in biased residuals and lower goodness of fit $\left(\mathrm{R}^{2} 0-23 \%\right.$ lower).

The daily mean excretion of AFCF from sheep with 1, 2 or 3 boli (Fig. 2) were described by the equations:

1 bolus: $\mathrm{Y}\left(\mathrm{mg} \mathrm{d}^{-1}\right)=42.2 * \mathrm{e}^{(-0.006 * \mathrm{t})}$

$$
\mathrm{R}^{2}=0.42
$$

2 boli: $\quad \mathrm{Y}\left(\mathrm{mg} \mathrm{d}^{-1}\right)=121.3 * \mathrm{e}^{(-0.012 * \mathrm{t})}$

$$
\mathrm{R}^{2}=0.76
$$

3 boli: $\quad \mathrm{Y}\left(\mathrm{mg} \mathrm{d}^{-1}\right)=362.5 * \mathrm{e}^{(-0.025 * \mathrm{t})}$

$$
\mathrm{R}^{2}=0.66
$$

According to these equations the mean daily excretion of AFCF decreased from day 10 to day 108 in sheep with 1 bolus from about 40 $\mathrm{mg} \mathrm{d}^{-1}$ to $22 \mathrm{mg} \mathrm{d}^{-1}$. For 2 boli the AFCF release decreased from 110 to $35 \mathrm{mg} \mathrm{d}^{-1}$, and for three boli from 280 to $25 \mathrm{mg} \mathrm{d}^{-1}$ (Fig. 2). The release rates of AFCF from animals with 1,2 and 3 boli were significantly different.

The mean retained mass of bolus material (Fig. 3) were described by the equations:

1 bolus: $\mathrm{Y}(\%)=103 * \mathrm{e}^{(-0.0077 * \mathrm{t})}$

$$
\mathrm{R}^{2}=0.99
$$

2 boli: $\quad \mathrm{Y}(\%)=100 * \mathrm{e}^{(-0.0083 * \mathrm{t})}$

$$
\mathrm{R}^{2}=0.99
$$

3 boli: $\quad \mathrm{Y}(\%)=95 * \mathrm{e}^{(-0.0138 * \mathrm{t})}$

$$
\mathrm{R}^{2}=0.99
$$

After 108 days $50-55 \%$ of the bolus mass was excreted in animals with 1 and 2 boli and $75 \%$ for animals with 3 boli (Fig. 3). The fractional 


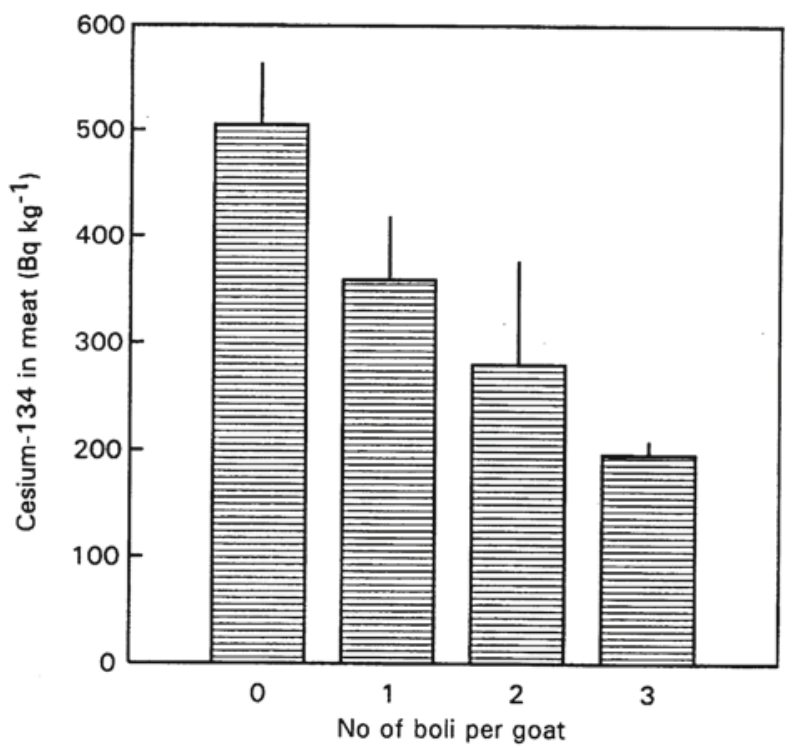

Figure 5. Meat ${ }^{134} \mathrm{Cs}$ activity concentration measured by live monitoring of control goats and goats treated with 1,2 or 3 boli in experiment 2. A solution of $1870 \mathrm{~Bq}{ }^{134} \mathrm{Cs}$ was given daily for 43 days. Measurements were taken at the end of the experiment. (Mean and standard deviations for 4 goats).

rate constants $(\mathrm{k})$ describing the relative loss of bolus mass were not significantly different. After about 2 weeks 1 bolus was regurgitated in 2 rams with 3 boli each. The boli were partly destroyed by chewing while another part of the bolus was found in the feed-crib. This caused subsequently high rates of AFCF excretion in feces 2 and 4 days later (470 and 490 $\mathrm{mg} \mathrm{d}^{-1}$, data excluded from Fig. 2). Variation in daily mean excretion of AFCF was considerably higher in animals treated with 2 and 3 boli than in animals which received only 1 bolus.

\section{Experiment 2}

The ${ }^{134} \mathrm{Cs}$ activity concentration in milk increased within 10-12 days to a plateau of 12 $13 \%$ of the administered amount per litre of milk ( $F_{m}$ values of $0.12-0.13 \mathrm{~d} \mathrm{l}^{-1}$, Fig. 4). When plateau levels were compared milk
${ }^{134} \mathrm{Cs}$ activity concentration was reduced by $35 \%, 60 \%$ and $85 \%$ for goats with 1,2 and 3 boli, respectively (Fig. 4). The plateau levels in the 4 groups were significantly different. The mean live monitoring measurements after 43 days of administration gave meat ${ }^{134} \mathrm{Cs}$ levels of $500 \mathrm{~Bq} \mathrm{~kg}^{-1}$ for the control animals ( $\mathrm{F}_{\mathrm{f}}$-value of $0.27 \mathrm{~d} \mathrm{~kg}^{-1}$, Fig. 5). Meat ${ }^{134} \mathrm{Cs}$ level were reduced by $30 \%(\mathrm{p}<0.05)$ in goats with 1 bolus, while 2 and 3 boli reduced the levels by $44 \%(\mathrm{p}<0.05)$ and $60 \%(\mathrm{p}<0.05)$, respectively (Fig. 5).

\section{Experiment 3 and 4}

Cesium-134 activity concentration in milk from control goats increased to a level of $12 \%$ of the daily administered amount per litre (Fig. 6). Milk ${ }^{134} \mathrm{Cs}$ activity concentration from the treated animals was reduced by $80 \%$ the first month, then the reduction gradually 


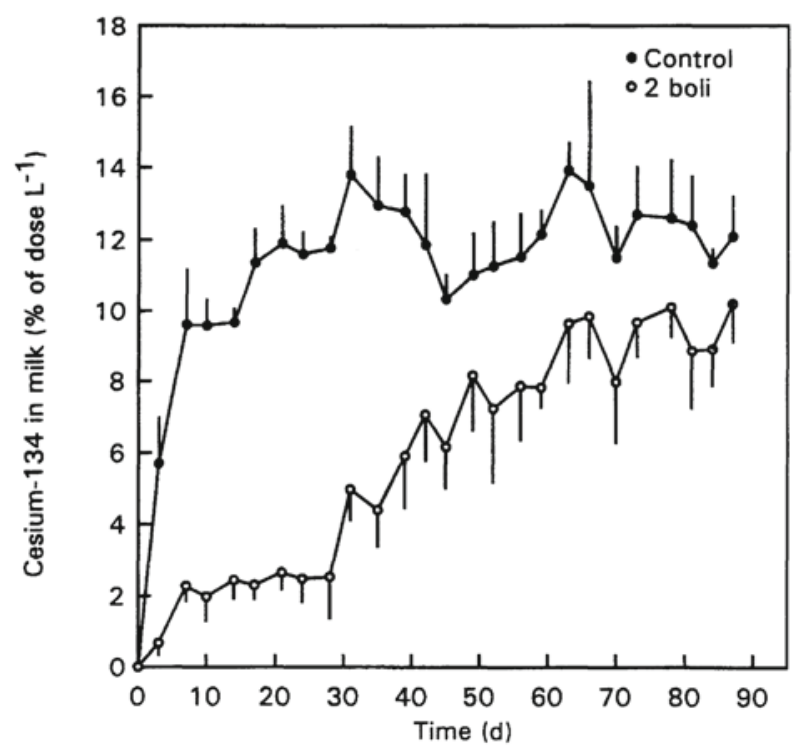

Figure 6. Fraction of the daily administered ${ }^{134} \mathrm{Cs}$ amount transferred to milk in 4 control goats and 6 goats treated with 2 boli in experiment 3 . A solution of $2360 \mathrm{~Bq}{ }^{134} \mathrm{Cs}$ was given daily for 87 days. (Mean and standard deviations).

decreased and about $20 \%$ reduction was observed from day 65 to 90 (Fig. 6). Nearly identical results were obtained when boli were tested after 1 year irrespective of the storage temperature.

\section{Discussion}

Shortly after administration the ends of the boli were rounded off. Later loss of material occured from the whole surface area (Fig. 1). Boli were nearly always found in the reticulum of slaughtered animals (H. S. Hansen pers. comm.). The reticulum contracts several hundred times each day and empties most of its contents into the rumen. Material with a high density will nevertheless remain at the bottom during the contractions. Since the density of boli collected from the sheep forestomachs after more than 1 month was the same as the original boli (H. S. Hansen pers. comm.) it can be concluded that boli dissolve from the surface. This is consistent with the first order kinetics demonstrated for the fecal excretion of ${ }^{137} \mathrm{Cs}$-iron-hexacyanoferrate complex (Fig. 2 and 3).

Friction between the reticular epithelium and the bolus removes material from the surface of the bolus. When several boli were given the release rates of $\mathrm{AFCF}$ were greater than those which would be expected solely from the increased mass of bolus material. This probably indicate that friction between the boli did release additional amounts of AFCF (Fig. 2). The density of $2.6 \mathrm{~kg} \mathrm{l}^{-1}$ which was reached by adding barite to the bolus was necessary to secure retention in the forestomachs and prevent regurgitation. During experiment 1 with labelled AFCF 2 boli out of a total of 24 were regurgitated. Lower rates of regurgitation could probably be obtained by increasing the 
density, by substituting AFCF for barite, but would simultaneously result in reduced release rates of AFCF. In the experiments 2, 3 and 4 with goats no boli were regurgitated. In field trials with grazing sheep in Northern Ireland no boli were lost in 49 lambs and 39 lambs which were slaughtered 6 or 10 weeks after treatment, respectively (J. Pearce pers. comm.).

AFCF is released in the anterior part of the digestive system, and 2-5 days are therefore required before the AFCF released in the reticulum is excreted in the feces. This delay does, however, not affect cesium binding which occurs in the forestomachs and the small intestine (Staaland et al. 1990).

Labelling of the iron-hexacyanoferrate lattice can be accomplished with ${ }^{14} \mathrm{C}$ or ${ }^{59} \mathrm{Fe}$ (Giese 1988, Arnaud et al. 1988). In the present study the iron-hexacyanoferrate complex was labelled with ${ }^{137} \mathrm{Cs}$, and the label was therefore not a part of the iron-hexacyanoferrate lattice. A benefit from our approach was that both the labelled and unlabelled AFCF in the boli were from the same batch of production. The fact that we did not detect ${ }^{137} \mathrm{Cs}$ in urine samples from the experimental animals at the end of the experiment demonstrated a sufficient stability of the ${ }^{137} \mathrm{Cs}$-iron-hexacyanoferrate complex.

A $\mathrm{F}_{\mathrm{m}}$-value of $0.12 \mathrm{~d} \mathrm{l}^{-1}$ in the control goats agrees well with other results of transfer of tracer ${ }^{134} \mathrm{Cs}$ to sheep and goat milk (Vandecasteele et al. 1989, Hansen \& Hove 1991). Reductions of $35 \%, 60 \%$ and $85 \%$ obtained in animals treated with 1,2 and 3 boli, are in accordance with the rates of reduction expected from the calculated AFCF release (experiment 1), and the reductions obtained when feeding similar doses of AFCF to reindeer (Hove et al. 1991). The $F_{f}$ value of $0.27 \mathrm{~d}$ $\mathrm{kg}^{-1}$ agrees well with other $\mathrm{F}_{\mathrm{f}}$ values estimated after tracer dosing of lactating goats (Hansen
\& Hove 1991) and is within the range reported for adult sheep (Howard 1989, Vandecasteele et al. 1989). The results from live monitoring measurements showed for all goats and treatments a somewhat lower reduction in the transfer of radiocesium to meat than to milk. Similar results were also observed in field studies (Hove et al. 1990). The reductions in this experiment were considerably higher than those reported by Pearce et al. (1989), which were obtained with sustained release boli made with saturated fatty acids instead of bees wax.

The high reduction in transfer of ${ }^{134} \mathrm{Cs}$ to milk $(80 \%)$ lasted for 30 days after treatment with 2 boli (experiment 3 ). From this time onwards the gradual loss of efficiency could most likely be explained by a reduced rate of release of AFCF from the dissolving boli. In experiment 2 a reduction of $85 \%$ was maintained for 43 days with 2 boli. This discrepancy between the effect in experiment 2 and 3 can probably be explained by differences in the mass of the boli (Table 1).

It is concluded that a single treatment with 2 AFCF boli reduced the transfer of ${ }^{134} \mathrm{Cs}$ by $80 \%$ in milk and $60 \%$ in meat over a 4 to 6 week period in small ruminants. Boli may be stored for extended periods without loosing their efficiency.

\section{Acknowledgements}

This study was supported by a grant from the Norwegian Agricultural Research Council. We appreciate the good care of the animals taken by A. Walle, A. Westre, R. Eikanger and A. Klaumann and the laboratory assistance by N. P. Asper and G. Østby.

\section{References}

Arnaud MJ, Clement C, Getaz F, Tannhauser F, Schoenegge R, Blum J, Giese W: Synthesis, effectiveness and metabolic fate in cows of the cae- 
sium complexing compound ammonium ferric hexacyanoferrate labelled with ${ }^{14} \mathrm{C}$. J. Dairy Res. 1988, 55, 1-13.

Daburon F, Archimbaud Y, Cousi J, Fayart G, Hoffschir D, Chevallereau I, Le Creff $H$ : Radiocaesium transfer to ewes fed contaminated hay after the Chernobyl Accident: Effect of vermiculite and AFCF (Ammonium Ferricyanoferrate) as countermeasures. J. Environ. Radioact. 1991, 14, 73-84.

Giese WW: Ammonium-ferric-cyano-ferrate (II) (AFCF) as an effective antidote against radiocaesium burdens in domestic animals and animal derived foods. Br. vet. J. 1988, 144, 363-369.

Giese WW: Countermeasures for reducing the transfer of radiocesium to animal derived foods. Sci. Tot. Environ. 1989, 85, 317-327.

Hansen HS, Hove K: Radiocesium bioavailability: transfer of Chernobyl and tracer radiocesium to goat milk. Health Phys. 1991, 60, 665-673.

Hove $K$, Ekern A: Combating radiocesium contamination in farm animals. In: Låg J. (ed): Health problems in connection with radiation from radioactive matter in fertilizers, soils and rocks. Oslo, Norwegian University Press, 1988 pp. 139153.

Hove K, Hansen HS, Strand P: Experiences with the use of caesium binders to reduce the radiocaesium contamination of grazing animals. In: Flitton S, Katz EW (eds): Environmental contamination following a major nuclear accident. Vienna, International Atomic Energy Agency, IAEA-SM-306, 1990 pp. 181-189.

Hove $K$, Staaland $H$, Pedersen $\emptyset$ : Hexacyanoferrates and bentonite as binders of radiocesium for reindeer. Rangifer 1991, 11, 43-48.

Howard BJ: A comparison of radiocaesium transfer coefficients for sheep milk and muscle derived form both field and laboratory studies. Sci. Tot. Environ. 1989, 85, 189-198.

Howard BJ, Beresford NA: Chernobyl radiocaesium in an upland sheep farm ecosystem. Br. vet. J. 1989, 145, 212-219.

Jones BEV, Eriksson O, Nordkvist M: Radiocesium uptake in reindeer on natural pasture. Sci. Tot. Environ. 1989, 85, 207-212.

Nigrovic V: Enhancement of the excretion of radiocesium in rats by ferric cyanoferrate(II). Intern. J. Rad. Biol. 1963, 7, 307-309.

Pearce J, Unsworth EF, McMurray CH, Moss BW, Logan E, Rice D, Hove $K$ : The effects of prussian blue provided by indwelling rumen boli on the tissue retention of dietary radiocaesium by sheep. Sci. Tot. Environ. 1989, 85, 349-355.

SAS Institute Inc.: SAS users Guide: Statistics (Version 6, fourth edn). Cary, N C. USA. 1990.

Staaland H, Hove K, Pedersen $\emptyset$ : Transport and recycling of radiocesium in the alimentary tract of reindeer. Rangifer Special Issue 1990, 3, 63-72.

Strand P, Brynhildsen L: Rapid method for live monitoring of cesium activity in sheep, cattle and reindeer. In: Flitton S, Katz EW (eds): Environmental contamination following a major nuclear accident. Vienna, International Atomic Energy Agency, IAEA-SM-306, 1990 pp. 485-486.

Unsworth EF, Pearce J, McMurray CH, Moss BW, Gordon FJ, Rice D: Investigations of the use of clay minerals and prussian blue in reducing the transfer of dietary radiocaesium to milk. Sci. Tot. Environ. 1989, 85, 339-347.

Vandecasteele CM, Van Hess M, Culot JP, Vankerkom J: Radiocesium metabolism in pregnant ewes an their progeny. Sci. Tot. Environ. 1989, $85,213-223$.

Ward GM, Johnson JE: Validity of the term transfer coefficient. Health Phys. 1986, 50, 411-414.

Watari $K$, Imai $K$, Izawa M: Radiochemical application of "iron ferrocyanide-anion exchange resin”. J. Nucl. Sci. Technol. 1968, 6, 309-312.

\section{Sammendrag}

Reduksjon $i$ overføring av radiocesium til husdyr produkter ved bruk av vomtabletter med ammoniumjern (III) - hexa cyanoferrat (II).

Fremstilling og virkninge av vomtabletter (boli) med ammoniumjern(III)-hexacyanoferrat(II) (AFCF) som cesium binder beskrives. Tablettene veide $40-50 \mathrm{~g}$ og ble produsert ved å presse en blanding av AFCF, barytt og bivoks under høyt trykk. Frigjøringen av AFCF fra vomtabletter plassert i vom-nettmage hos sau ble studert i laboratoriefors $\varnothing \mathrm{k}$. En del av AFCF i vomtablettene ble merket ved reaksjon med ${ }^{137} \mathrm{Cs}$ før vomtablettene ble presset. Frigjøringen av AFCF fulgte førsteordens kinetikk under den 108 days observasjonsperioden og sank fra 40 til $22 \mathrm{mg} \mathrm{d}^{-1}$ hos dyr som fikk en vomtablett og henholdsvis 110 til 35 og 280 til $25 \mathrm{mg} \mathrm{d}^{-1}$ hos dyr som fikk to og tre vomtabletter.

Virkningen av AFCF vomtabletter på overføring av radiocesium til melk og kjøtt ble studert i 
laboratoriefors $\varnothing \mathrm{k}$ med geiter som daglig ble gitt ca. 2 $\mathrm{kBq}{ }^{134} \mathrm{CsCl}$ på fôret. Den første måned etter behandling var reduksjonen $\mathrm{i}{ }^{134} \mathrm{Cs}$ konsentrasjonen i melk $35 \%, 60 \%$ og $85 \%$ hos geiter som fikk henholdsvis en, to eller tre vomtabletter. Virkningen av vomta- blettene varte i 90 dager, men med avtagende effekt etter de første 30 days. En trinnvis reduksjon i innhold av radiocesium i muskelvev hos geiter avhengig av antall vomtabletter ble også observert med $60 \%$ reduksjon som det maksimale.

\section{(Received April 2, 1993; accepted April 23, 1993).}

Reprints may be requested from: K. Hove, Department of Animal Science, Agricultural University of Norway, N-1432 Ås, Norway. 